\title{
Four Roman Libraries
}

\author{
by Philip Harvey
}

anuary is named after Janus, the god of the doorway and a remarkable amount of time is spent in Rome simply passing through doors and gates. One such door leads into 1 Santi Silvestro e Martino ai Monti, a church with 3rd century foundations cared for by the Carmelite Order and only a stone's throw from the Colosseum. By good fortune I find myself here at a conference of the Carmelite Librarians' Association. The delegates are being guided through the church by Giovanni Grosso, a bearded and purposive Carmelite in seasonal duffle coat. He showed us such marvels as the carved tomb lid of the Provincial who gave Teresa of Avila permission to form a community of women, and a chapel to Our Lady made of over thirty different kinds of coloured marble. Adjacent to the church is the Carmelite General Curia, headquarters of the worldwide Order. Ascending the many floors of stone stairs that make for a heightening experience in Rome, we eventually entered the door of a small library, and rested.

But this is a library like few others. Giovanni is the Postulator General for the Causes of Carmelite Saints and this room is his haven, his mission, his challenge. Along one wall, floor to ceiling, are rows of the red folio volumes containing documentation for different saintly causes. In essence, a case must be collected to put before the Congregation for the Causes of Saints, one that includes proof of miracles performed after the holy person's death. This monumental collection is a donation from somewhere in Rome and to tell from Giovanni's groans and gesticulations (all in pretty good English), a donation he would rather have somewhere else again. We all need models of precision and comprehensiveness for our work, but how many example volumes of different saintly causes does one man need? The books stood in line with an authoritative finality.

On the opposite wall are rows of neat spring folders, each dedicated to a new cause, each accumulating leaves of information, each meticulously marked and ordered. But perhaps most fascinating of all, and not just for a bunch of librarians, is the locked room with the bound volumes (vellum, leather, parchment, paper, card) of Carmelites beatified and sainted. The Tridentine desire, informed by the nascent scientific expectations of the 16th century for what is verifiable and objectively provable, finds final form in these extraordinarily deliberate, decisive documents. These are more than just golden legends. They are arranged according to the Vatican system of classification, first by subject, then under each subject divided with the little ones on the top shelf at I, medium-sized books at II and III, folios in IV, and the truly elephantine at V. Under each subject and Roman numeral, the books are then numbered according to accession, which means the only things a cataloguer needs are a grasp of broad subject areas, counting skills and a ruler. The Vatican system is used in libraries all over the city. It reflects the mode of shelf arranging established in scriptoria in the Middle Ages. Giovanni's gracious introduction to his world was met with appreciative inspection of some very ancient records. The archivists among us were buzzing with excitement. Carmelites 
"The Library of

the Institutum

Carmelitanum is

housed on the other

side of the Tiber,

close to the walls of

the Holy See." recently beatified include the Italian charity worker Angelo Paoli (1642-1720) and the founder of the Sisters of Our Lady of Mount Carmel, Maria Scrilli (1825-1889). Also canonised in 2009 was Nuno Alvares Pereira, a 14th century soldier who secured Portuguese independence before entering the Order; he has been for centuries the official Patron of Portugal, so the Portuguese Government was rapt at the elevation of their national hero and awarded Giovanni one of their most distinguished honours in recognition of his hard work. Giovanni's job was made easier in 1983 when Pope John Paul II officially eliminated the position of Promotor Fidei, popularly known as the Devil's Advocate, whose task was to mount a case against the proposed canonisation. This has freed up the Postulator's job considerably, he can concentrate undistracted on the matter at hand. Some wags have suggested though that the elimination of this role is one reason why there has been such a surge of canonisations in the past thirty years.

\section{II}

The Library of the Institutum Carmelitanum is housed on the other side of the Tiber, close to the walls of the Holy See. From the roof there is a view of the great cupola of St. Peter's Basilica on one side and Castel Sant'Angelo on the other, so you could say that the Institute is centrally located. This is the largest Carmelite collection in the world and probably for that reason some creative design solutions have been found to absorb the new material. Part of the ornate chapel has been sectioned off, taking up two levels of the building. Into this space has been inserted the kind of iron framing used in shipbuilding to weld decks together and support massive loads. The result is impressive, though helps to explain the comment of one of the Indian Carmelites as we reached the entrance doors: Welcome to the Titanic! It is a great feat of engineering, likely to inspire the very opposite of a sinking feeling. Air flows through the levels. Light lines the shelves. Ancient and modern reside comfortably side by side. The new librarian, Ton van der Gulik, O.Carm., finds the top level too hot in summer, too cold in winter, but for most of the year it is a pleasurable working place. Ton and his assistant, Ana Gina Sembrano, have their work cut out for them, with 400 periodicals to manage, a steady flow of books to process in any number of languages, and all the niceties of a contemporary network. The Library uses the Vatican classification system and the catalogue is online.

Although the collection has incunabula and a depth of material from every period since, the Library itself was only started in 1948. It stands in a line with much older libraries, such as that of the General Curia and the Roman studium, which were expropriated by the Italian state in the critical year of the risorgimento, 1870 . The Institute Library is an expression of the certainty and optimism of the immediate post-war church. The foundation collection was from 
"Like so many

libraries in Europe, access to the

\section{collection is limited.}

\section{The reader needs}

to make a prior

appointment with

the librarian even

to get inside or

near the works.

... it is easy to see

why restrictions are

necessary. To start

with, the Institute

Library holds the

only copy of many

titles and often

the only copy in

Rome itself. Theft is

known and loss of

books is a blow."
St. Albert's International College in Rome, but at the instruction of the Provincial Kilian Lynch, books from other house libraries in Italy and abroad were collected and added to the Library. This in some ways is the example for the practice of collecting books at the Carmelite Library in Australia, in fact Paul Chandler O.Carm., librarian of the Australian Library for 15 years has said that the Institute Library and its methods are the inspiration for much that has been achieved in Middle Park. There are many sources for good books and a librarian with initiative will be on the lookout for all of them. Another steady source of relevant new titles was made permanently available in 1953 when the Order's General Chapter decreed that all provinces and members of the Order should send two copies of their books to the Institute Library, a kind of religious legal deposit system. It would be interesting to know if this comes any closer to comprehensiveness than similar systems at national libraries worldwide, although clearly submission of new Carmelite titles to Rome has the added incentive of instant inclusion in the great Bibliographia Carmelitana Annualis. The card files for this massive undertaking are kept in painstaking order and can be inspected with reverence in cabinets lining one of the corridors. Also, the Carmelite Order's 95 year-old historian Joachim Smet, O.Carm. has a card file of his own for historical data. He makes cards for the books he acquires for the library in Washington. The manual work of collecting and arranging data, whether on page, card or screen, remains part of our daily occupation.

Like so many libraries in Europe, access to the collection is limited. The reader needs to make a prior appointment with the librarian even to get inside or near the works. Although this may seem severe to those of us conditioned to general open access to our collections, it is easy to see why restrictions are necessary. To start with, the Institute Library holds the only copy of many titles and often the only copy in Rome itself. Theft is known and loss of books is a blow. Not only do many of the books have a high monetary value, even those that haven't a high price do have a value in research and Carmelite terms that cannot be defined. Distant collections and online digital e-book databases cannot remedy the fact of an irreplaceable book. Another problem for Ton is the lucrative market in Italy for printed pages and art prints in old books. He explained to delegates at the conference one method of removing priceless title pages from ancient tomes. First you sit in a place out of sight of librarians. Then you untie your shoe lace, lick the cap at the end, and run the incisive edge down the inside of the page. As one of the Washington delegates, Patrick McMahon, O. Carm., then said, Thanks for the tip! Ton, a Netherlander, owned to being a believer in original sin and one could reflect that he had come to work in a city where that belief is fairly well confirmed on a daily basis. We know how Ton feels. Librarians are not employed just to maintain 24 hour surveillance on the users and even the installation of cameras and other devices is not going to 


\section{"Swiss Guards in}

grey and powder

blue uniforms stand

in the road of the

Porta Sant'Anna, waving through

little cars, reading

someone's papers,

pushing back a

stray tourist. Our

credentials must be

good, as they soon

start the process

of counting us and

briskly pointing

us up the road to

the Cortile del

Belvedere." deter those with an eye on the illegal market. What to do. Our first commitment to excellence in research and availability of all the best sources should not be compromised by our concerns about theft and vandalism, no matter how justified those concerns may be.

On a lighter note, another reason for prior appointment is related to the classic hours of opening in Rome, open in the morning until 12.30 , re-opens at 4 until 8 . As with nearly everything in this place, official noticeboards never mention the holy hour of siesta after lunch, or need to.

III

They have had eighteen months to work this out, states our Carmelite host. The first Carmelite conference since Madrid in July 2009 and still his request for a visit to the Bibliotheca Apostolica Vaticana is being turned over by the cardinal after the guests have arrived, the cardinal librarian or the prefect of the library I couldn't exactly gather which. Negotiations continue behind the scenes as our conference proceeds, with updates that veer from the upbeat to the despairing. But our host is like that, amused but practical, blunt and then diplomatic, candid and then mysterious, like so many Maltese, and Maltese with a lifetime of working the Vatican networks. He is embarrassed on our behalf. He is someone who can make light of the more grandiose papal absurdities but then state, as though it were of no particular moment, that he spent hours talking to Joseph about our mealtime subject of conversation, when he was still cardinal. Eventually, on about Day Three, our host Mark Attard, O. Carm. announces during primo piatto at lunch, that we have got in. Bravos fill the dining room of the Domus Carmelitana. There are celebratory sips of chianti.

So, on the evening in question we all gather to walk the couple of blocks to the local library. Swiss Guards in grey and powder blue uniforms stand in the road of the Porta Sant'Anna, waving through little cars, reading someone's papers, pushing back a stray tourist. Our credentials must be good, as they soon start the process of counting us and briskly pointing us up the road to the Cortile del Belvedere. As we proceed into the "foreign country" of Vatican City one of the Carmelite librarians from Mainz says to me that he has handed in his membership to Al-Quaeda as he feels the organization has developed an attitude problem. Black humour is not dead in Germany. Certainly we know that Rome has been on alert for weeks, with news of mail bombs being sent to embassies all over the city. The Portuguese Embassy had one defused only a couple of days previously. However this is not Islamist terrorism but the work of a homegrown anarchist group.

Scale means stairs, doorways, walls, windows, cliffs of walls and windows reaching into the sky. The Belvedere imposes the memory of history with its own physical immensity. At one end of this huge courtyard stands the Vatican Library, newly re-opened after three 


\section{"Nothing truly} human is foreign to the Church. For this reason she has always sought, gathered and preserved, with a continuity rarely matched, the best results of the efforts of human beings to rise above the purely material to the conscious or unconscious search for the Truth." years of renovations to the 16th century building. One of the first things Benedict XVI did upon becoming pope was to close the Library, much to the disgruntlement of scholars. Now the results are on show. One of the themes of this pontificate is the protection and renewal of cultural heritage. There is a special concern with upgrading the European inheritance. Benedict's own words on the 9th of November 2010 at the official re-opening are worth reading:

"Far from being merely the result of the daily accumulation of a refined bibliophilia and the random collection of works, the Vatican Library is a valuable means - which the Bishop of Rome cannot and does not intend to give up - which enables him when considering problems in a perspective of long duration to perceive the distant roots of situations and their evolution in time. While it is an eminent place of the historical memory of the universal Church in which venerable testimonies of the manuscript tradition of the Bible are preserved, the Vatican Library nevertheless has another reason for being the object of the care and concern of the Popes. Since its origins it has preserved the unmistakable, truly "catholic" universal openness to everything that humanity has produced down the centuries that is beautiful, good, noble and worthy (cf. Phil 4:8); hence the breadth with which in time it has gathered the loftiest fruits of thought and of human culture, from antiquity to the Middle Ages, from the modern epoch to the 20th century. Nothing truly human is foreign to the Church. For this reason she has always sought, gathered and preserved, with a continuity rarely matched, the best results of the efforts of human beings to rise above the purely material to the conscious or unconscious search for the Truth."

The main objective of the renovations was to improve security. To me the most amazing aspect of this is the Pergamon system for tracing books. Inside each volume is placed an electronic chip, a sound detector. Each detector has its own unique sound frequency, which means that a sensor can find the book anywhere in the Library. The theory is that books will never get lost again. Clearly there has been a history of books being moved around the library so they become untraceable. Exactly how many volumes have been prepared in this way is a mystery, our guide being more keen to tell us that the new system is underway. There are also the more mundane security arches at the entrances, which are activated if someone tries to leave the room with a book. Mere statistics take on new meaning in this context. The Vatican Library has fifty kilometres of shelving, over 1.6 million volumes, and 150,000 manuscripts.

After introducing us to a very old, queer statue guarding the entrance that may or may not be Hippolytus, our guide took us up stairs and lifts to the various grand rooms of the Library. The treasures are not all bibliographical. For example, framed on one wall of a corridor was a gigantic map of the world, drawn on rice paper by one of the Jesuit astronomers who visited China in the 17th century, probably Ferdinand Verbiest. It shows all the continents of the world, 


\section{"Undoubtedly the}

most sensational

room in the Library

is the Salone

Sistino, 70 metres

long and 15 metres

wide."
Africa, Asia, Europe, the Americas. I piped up with, "And Australia?" "Oh," replied our guide, "the newcomers. No, not Australia, yet."

Undoubtedly the most sensational room in the Library is the Salone Sistino, 70 metres long and 15 metres wide. The room is painted with frescoes throughout, is superbly lit with natural light, and served as the main reading room for centuries. It will become so again when the space has been fully refurbished. This is the room visitors glimpse via the passage on their way to the Sistine Chapel. The iconography, if you like, of the paintings expresses Renaissance ideas about the written word and the book, with Jesus Christ at the top of the room, Alpha and Omega. It is here you see both physically and in pictorial form how much the Vatican Library is a product of Renaissance Humanism, with its serious intentions of joining the knowledge of the rediscovered classical world (everywhere abundant in Rome) with that of the Christian world that superseded it.

Rooms lead to other rooms until you wonder if the whole world is rooms, or, Janus-like, consists of doors leading to more doors. In fact, the Library's collection development is very focussed and like all great libraries, does not just take everything. I was particularly conscious of the emphasis on transmission of the written word. I spent the best part of my time viewing the shelves of books in the palaeography room, truly the most amazing reference resource anywhere for those studying, but more especially deciphering and dating any written or printed book over the last two millennia, and beyond. May I point out too, that even if all of these books are eventually digitised, you would not be able to locate what you wanted quicker online than in this room, where the highly specialist books come as close to completeness as can be hoped for in this life. They are easy to read and easy to reach. The question here of what the naked eye can see on a printed page clearer than on a computer screen is one we will be hearing more about, now that some people think that digital is the answer to all prayers. In order to study here one has to be an expert in specialised publications, a teacher or university student doing a $\mathrm{PhD}$, so there are serious limits to who may even come into the Library. You have to be here for a very good reason.

Another impressive aspect of the Vatican Library is its school of library science, founded by Pope Pius XI, himself a librarian, in 1934. Although we don't expect our libraries to start up their own library schools in situ, the presence of this school reminds me that we should be thinking of our libraries as library schools, places where the trainee librarian as well those at any stage of learning on the job keep learning new skills, acquiring new knowledge, sharing the control of information with all those similarly engaged.

The Library has its own binding, restoration and preservation workshops for books and manuscripts. It has also embarked on a digitisation project, a work expected to be realised in ten years. Indeed, it is the workshop spaces of the Vatican Library that have 


\section{"In the Vatican}

Library all seekers of the truth have

\section{always been}

welcomed with

attention and

respect without

any confessional

or ideological

discrimination;

all that is asked of

them is the good

faith of serious, disinterested and

well-qualified

research." been given the greatest attention during the three-year restoration, a complete overhaul.

We were left to peruse our favourite areas of discovery before our guide called time. More words from the same speech of Benedict's ring true to those who have experienced this Library first-hand. They express well the spirit of this place, as well as informing the thinking behind our own enterprises and I quote at length:

"The Vatican Library is therefore not a theological or predominantly religious library; faithful to its humanistic origins it is by vocation open to the human being. It thus serves culture, that is to say, as my Venerable Predecessor, the Servant of God Paul VI said on 20 June 1975 on the occasion of this institution's fifth centenary, "human maturation... growth from within... an exquisitely spiritual acquisition; culture is the elevation of the most noble faculties that God the Creator has bestowed on man, to make him a man, to make him more of a man, to make him like Himself! Culture and mind therefore; culture and soul; culture and God. [...] This institution, too, the Church re-proposes to us these essential and vital binomial aims, which touch man in his truest dimension, and, as if by an inversion of the law of gravity, incline him upwards, and urge him... to go beyond himself in accordance with the admirable Augustinian trajectory of quaerere super se (cf. St Augustine, Confessiones, X, 6, 9: PL 32, 783). With the operation of this "female" institution, the Church sets out today - as she did five centuries ago - to serve all people, including her ministry in the wider framework of her essential ministry as the Church: the Church as a community that evangelizes and saves" This openness to the human being is not only addressed to the past but also looks at the present. In the Vatican Library all seekers of the truth have always been welcomed with attention and respect without any confessional or ideological discrimination; all that is asked of them is the good faith of serious, disinterested and wellqualified research. In this research the Church and my Predecessors have always recognized and appreciated a religious motive, often unconscious, because every partial truth is part of the Supreme Truth of God and every thorough and meticulous investigation to ascertain it is a path to reach it.

"Love of literature and historical and philological research are therefore interwoven with the longing for God, as I had an opportunity to say on 12 September 2008 in Paris ... recalling the great experience of Western monasticism. The monks' objective was and remains that of quaerere Deum, seeking God. The search for God intrinsically requires a culture of the word. The longing for God, the désir de Dieu, includes amour des lettres, love of the word, exploration of all its dimensions. Because in the biblical Word God comes towards us and we towards him, we must learn to penetrate the secret of language, to understand it in its construction and in the manner of its expression. Thus it is through the search for God the 


\section{"The Vatican}

Library is therefore the place in which the loftiest human words are gathered and kept, the mirror and the reflection of the Word, the Word that enlightens every man (Jn 1:9)." secular sciences take on importance, sciences which show us the path towards language.

"Because the search for God requires the culture of the word, it was appropriate that the monastery should have a library, pointing out pathways to the Word. It was also appropriate to have a school, in which these pathways could be opened up ... The monastery serves eruditio, the formation and erudition of man - a formation whose ultimate aim is that man learn how to serve God". The Vatican Library is therefore the place in which the loftiest human words are gathered and kept, the mirror and the reflection of the Word, the Word that enlightens every man (Jn 1:9). I am pleased to conclude by recalling the words that the Servant of God Paul VI spoke on his first Visit to the Vatican Library on 8 June 1964, when he recalled the "ascetic virtues" required by activity in the Library, immersed as it is in the plurality of languages, of writings and of words, but looking always at the Word, through what is temporary, ceaselessly searching for the definitive. Of this both austere and joyful ascesis of research, at the service of one's own studies and those of others, in the course of its history the Vatican Library has offered countless examples, from Guglielmo Sirleto to Franz Ehrle, from Giovanni Mercati to Eugène Tisserant. May it continue on the path marked out by these luminous figures!"

\section{IV}

Sung Eucharist is the main Sunday service at All Saints Anglican Church in Via del Babuino near the Spanish Steps. Epiphany was, by good fortune, conducted by David Richardson, Dean Emeritus of St Paul's Cathedral in Melbourne. These days, a Provincial Canon of Canterbury Cathedral, he resides in Rome, his main jobs being as the Archbishop of Canterbury's Representative to the Holy See and Director of the Anglican Centre. So, after the service David and I walked down Via del Corso, weaving between the Sunday worshippers, the Sunday shoppers, and the Sunday rubberneckers. A right turn took us into the quiet of Via del Collegio Romano, past a small oratory-church that is made available for weekday Anglican worship when the congregation at the Anglican Centre outgrows the tiny Chapel of Saint Augustine of Canterbury, then into the church of Sant'Ignazio, one of the two majestic Jesuit churches of the city. Sant'Ignazio is unnecessarily famous for its false dome, a vast painting on the ceiling that resembles a dome, the same angle of the dome from any angle. Sunshine does not break through. Such is the predilection for domes in the Eternal City that people will go to any lengths to have their own. David and I pondered awhile why the Jesuits would go to such trouble to maintain a trompe l'oeil. Are they pulling our leg or doing it on the cheap? As the Washington delegate at my conference was wont to say, Go figure! The Anglican Centre is situated in Palazzo Doria Pamphilj just nearby, so after further clanking of solid keys into topheavy doors, and the soft shuffle 
"This is a dream

library, with

windows looking

out onto palm trees

and streetscapes,

tempting
armchairs,

parquetry floors,

even the latest

internet screen to

assure you there

is a world beyond

Rome." across some of the deepest marble steps I have ever seen (two feet deep, surely), we arrived on the first floor. The Palazzo, the largest privately-owned palazzo in Rome with one of the finest private art collections in the world, is the possession of the Doria Pamphilj family; the former (Doria) a Genoan family, the latter (Pamphilj) a Roman family. Innocent X (1574-1655) was the Pamphilj Pope. The family has been immensely generous to the Anglican Communion, providing a home for the Anglican Centre within the Palazzo since 1966. Here Anglicanism feels much at home.

Indeed so. We entered a large and beautiful room with shelving on all sides and a spiral staircase leading to a mezzanine, containing yet more of the Anglican Centre Library. This is a dream library, with windows looking out onto palm trees and streetscapes, tempting armchairs, parquetry floors, even the latest internet screen to assure you there is a world beyond Rome. Nearly all the books are in English, an anomalous sight in itself given the circumstances, but then the core business is la chiesa inglese. David left me to study the spines. The library is founded on the donation of the collection of John Moorman, Bishop of Ripon. J. R. H. Moorman (1905-1989) was someone who could genuinely be described as an Anglican Divine. Two books of his that should be in any theological library are 'A History of the Church in England' (3rd rev. ed., 1973) and 'The Anglican Spiritual Tradition' (1983). He wrote extensively on Franciscanism, a subject well-represented in the Library, though it is said that many of his Franciscan books went to St Deiniol's Library in Wales. Historically, Moorman is important in leading an Anglican delegation to the Second Vatican Council and in 1967 chairing the Anglican Commission that led to the formation of the AnglicanRoman Catholic International Commission. Understandably therefore, the library is well-served in meeting its prime dedication to the study of Anglicanism and ecumenism. The Library is rich in church history and the incredible reach of the Anglican Communion worldwide. It holds books, journals and other published works on theology, history, ministry and mission, liturgy and literature. It strives to hold current journals and newspapers from around the world. Scholars and students, not to mention librarians visiting Rome, are welcome to visit the library. The catalogue is online and classification is Dewey, so there is a mass of literature at 283.

The Anglican Centre itself provides a permanent diplomatic presence in Rome - unique in world Christianity - for the Anglican Communion. It is the base for the Archbishop of Canterbury's Representative to the Holy See. It provides a ministry of prayer and hospitality. It gives advice on pilgrimages and visits to Rome. Perhaps most importantly in general terms, the Centre contributes to conversations and builds friendship between Anglicans and Roman Catholics at every level. It encourages and resources working and growing together in unity and mission. 
With only one afternoon free before going home, there was still much to do. Vespers at the Vatican is something else. The city outside was a continuing swirl of action. Across the street from the Anglican Centre is the old theology school known as the Roman College, founded by Pope Gregory XIII (1502-1585), with its rose-coloured astronomy tower on the roof. It was here, David remarked, that the Gregorian Calendar was devised in 1582. It's good to know which day it is. David and I walked down Via del Gesù comparing Melbourne notes (nothing too surprising) before I went off to commit the cliché at Trevi Fountain, and David went back to work.

"Across the street from the Anglican Centre is the old theology school known as the Roman College, founded by Pope Gregory XIII (15021585) ... It was here ... that the Gregorian Calendar was devised in 1582." 